\title{
The security state
}

Chapter 2 offered not only a critique of the NSD, but also sketched alternatives to its theories of justice and citizenship. I now want to examine two further debates that will not only refer us to back to some of the other critiques offered in Chapter 1, but will also act as a platform for Chapter 8 when we examine an important aspect of ecowelfare. Here, the intention is not so much to analyse the principles of community, meritocracy, reciprocity and inclusion as to understand the means by which the NSD seeks to secure and enforce these principles. The first debate concerns globalisation and I want to suggest that the NSD is congruent with a kind of globally-oriented state that possesses both conservative and social democratic features. This state corresponds particularly to recent developments in the UK and USA and so my analysis will draw upon a range of scholarship dealing with these countries. The second debate follows on from this and deals with information. My premise here is that the global information society is ordered around some familiar structures of power and domination that many accounts tend to neglect in their breathless enthusiasm for new technologies.

So we begin with globalisation and an account of what I shall call the 'security state'; this section aims to do nothing more than lay the ground for the following, longer discussion of information. We then return to other important aspects of globalisation in the next chapter. So as before the intention here is not to review each and every feature of these debates, but merely those that will allow a theory of ecowelfare to emerge.

\section{Globalisation}

With this last point in mind we can proceed to a brief overview of Bauman's account of globalisation, since Bauman captures very succinctly 
the kind of social and spatial polarities that are crucial to understanding the security state and so to understanding recent developments in the US and UK. I will be assuming that globalisation is an economic, political and social reality, but one that can accommodate a much wider range of ideological trajectories than those proposed by conservatives and new social democrats. For a defence of my stance on globalisation see Fitzpatrick (2001d).

Bauman (1998a, 1998b, 2001) describes the annihilation of spatial and temporal distances as a situation where the wealthiest are now able to free themselves from the localities that immerse the poor in immobility. To put it simply, the sites that are deterritorialised at the global level are reterritorialised at the local and economic inequalities have polarised space to the point of fracture (Harvey, 1996). This spatial polarisation is partly physical, as the public space of social interaction is replaced by 'interdictory spaces' that keep the polarities apart, and partly virtual: the electronic database centres itself within these exclusionary dynamics, e.g. credit ratings determine our degree of mobility/weightlessness or immobility/density (Fitzpatrick, 1999b). Globalisation therefore represents a structural distinction between two worlds that only appear to inhabit the same ontological field: the cosmopolitan elites (the tourists) live primarily in time, moving effortlessly through geographical and electronic borders; the excluded (the vagabonds) live primarily in space, weighted down in the immobile present by the monotony of meaningless time (Bauman, 1998a: 88-9).

A raft of policies is therefore brought to bear against vagabonds in order that the tourists' consumption of both their present and (likely) future status is stimulated. The increase in rates of incarceration is the most obvious way in which the privileged try to insure themselves against the insecurities that they misidentify as emanating from the excluded, and virtually the entire panoply of the security and surveillance industry can be interpreted as the refortification of class divisions and the criminalisation of poverty (Bauman, 1998a: 113-22; Short and Kim, 1999: 115-16), expressed most alarmingly in the ghettoisation of rich and poor areas (Body-Gendrot, 2000).

Bauman's account is not without problems (Warde, 1994), especially given his tendency to make sweeping generalisations that fit whatever metaphor he is captivated by at that moment. Even so, he is one of those whose approach is a welcome alternative to those who treat globalisation as a rupture in the historical condition (Giddens, 1991) and those who regard it as little more than an ideological fiction that inevitably functions according to capitalist imperatives (Bourdieu, 1998). The following exploration of the security state therefore follows the kind of lead that Bauman suggests. 
Two caveats must be noted, however. First, this is not meant to be a general, all-purpose description of the globally-oriented state. States around the world are following a variety of trajectories according to the political and economic strategies adopted and the institutional background at work. Indeed, Chapter 4 will suggest that 'old' social democracy is far from dead, precisely because there is far more heterogeneity than accounts of the investment state, or the competition state, or the workfare state, or whatever, normally allow for. Even so, I neither want to underestimate the degree of state convergence that globalisation implies and the 'security state' is a working hypothesis that I apply to the UK and USA, two countries in which the NSD has arguably been most influential. Second, however, this is not to insinuate that the security state is a product of the NSD; indeed, it would make more sense to reverse the relation and argue that the NSD is a product of the security state. More accurately, the NSD and the security state can be regarded as aspects of one another. The UK and the USA are two countries within which conservatism arguably took the greatest hold so that, in reworking the welfare state and then, in turn, being reworked by the more limited social democracy of Clinton and Blair, conservatism has fashioned a political agenda that we can understand through the intellectual convergence of social policy and criminology. Therefore, the security state and the NSD are both consequences of conservative hegemonisation. I will therefore draw a picture of the security state in outline and then indicate why New Labour's main welfare and criminal justice reforms to date are consistent with it.

The state's job on the domestic front has traditionally been to weave order out of chaos: to prevent anarchy, to ensure historical continuity, to suppress revolution, to scapegoat minorities, to balance the fluctuations of economic supply and demand. As global capital becomes apparently unmanageable, as the polity and the economy detach after a century of alignment, the state can only now prosper if, in addition to weaving order out of chaos, it facilitates and manufactures much of that chaos in the first place in order to remain attractive in the eyes of capital. As the maintainer of order at the national level, the state has traditionally been the guarantor of stability (whether through constitutional or authoritarian means); under contemporary conditions it is just as often the instigator of instability and disorder by colluding with, failing to prevent or even generating global market forces - think of the World Trade Organisation (WTO), the Multilateral Agreement on Investment and the General Agreement on Trade in Services. So the chaos that the state now gives order to is often a chaos of its own making. As the state increasingly submits to the 
dominant logic of global capital, so it must socially and discursively construct threats that only it can address through what Jordan and Arnold (1995; Jordan, 1998: 183) call a 'politics of enforcement' (graphically illustrated by the reaction of the Genoa police to anti-WTO protesters in 2001). It helps to create the spatial polarisation that Bauman draws attention to and then represents itself as the principal means of depolarising and restabilising the resulting conflict (Zukin, 1991; cf. Hughes, 1996). The security state consists of a series of punitive responses to the chaos it has facilitated. ${ }^{1}$

Therefore, the state that withers away is only the macrointerventionist state, rematerialising at the micro-social level through a series of state, semi-state and non-state interventions (Cohen, 1994), criminalising those such as beggars, street-level entrepreneurs, claimants, the low paid, single mothers and teenagers (Cook, 1997: 131-52; Pavarini, 1997; Dean, 1999; Parenti, 1999). The state extends its reach by relaxing its grip. So although social spaces are polarised, they are also simultaneously subjected to a regulatory gaze where freedom and governance merge in new technologies of control (Rose, 1999; Garland, 2001): '. . . technologybased contexts of interaction that regulate, organise or monitor human behaviour by integrating it into a pre-arranged environment, built upon a conception of "normality" or "regularity" that all subjects are expected to reproduce' (Lianos with Douglas, 2000: 264).

But if these 'pre-regulated' spaces encompass both rich and poor territories, the asymmetries of power between those territories alter the means of reproduction within them (Fitzpatrick, 2001d). In the affluent territories the periphery consists of marginal people who must be both excluded and endlessly reimagined. Reproduction therefore consists of a constant vigilance against potential threats; otherness represents a source of victimisation and so must willingly subject itself to surveillance. If it does not, then because that which is non-monitored is equivalent to lawlessness then punitive measures are entirely justified. In the poorer territories, the periphery consists of wealthier lifestyles that are omnipresent and so must be emulated through recurrent debt and processes of 'clearance', constant proof that you are worthy of entry. These 'prudential' or 'actuarial' spaces enforce gestures of normality upon those the wealthier can no longer recognise as normal, i.e. as resembling themselves.

The security state therefore presides over a patchwork of preregulatory spaces that are polarised socially and symbolically between a series of alternating peripheries. Struggling to meet the basic needs of social security, it can reconfigure those needs as basic fears by operating as the simultaneous origin and resolution of global security risks. Once the gatekeeper who tried to protect against post-war turbulence; now the state invites the global turbulence to storm through the national economic and political 
walls that it generously offers to maintain. By engendering economies of risk and flexibility, globalisation demands both the collective enforcement of the duty to work (see Chapter 2) and the dismantling of the workplace regulations that threaten international competitiveness (Jordan, 1998: 82-3). And so we are collectivised into an active acceptance of our own passivity. This duty appears under several guises: as the overworked 'presenteeism' of the securely employed, as the on-call insecurities of the marginally employed and as the compulsory submission of unemployed claimants to the demands of the benefit system. Correspondingly, social entitlements are now based less upon having a voice within the workplace and more upon the capacity (though only for the lucky ones) to flee between workplaces: entitlements are possessed by 'job consumers' rather than cooperatively-organised workers. Thus, under pressure from global capitalism, the state assists in the individualisation of rights and the collectivisation of duties (Fitzpatrick, 1998a): the privatisation of common fate and the collectivisation and control of individual autonomy. Hence what I referred to in Chapter 1 as the desocialisation of society. Yet the security state's work is, literally, never done. The more obsessed with safety we become, then the less safe we feel because the more we monitor (in order to reduce our fears) then the more dangerous the non-monitored begins to appear. The security state therefore perpetuates itself infinitely.

Developments within the benefit system, both pre- and post-New Labour, illustrate this transformation (Fitzpatrick, 1998a). The principle of social insurance came to embody the commonality of fate by having both a spatial dimension (universality) and a temporal dimension (cradle to grave) and so was oriented both to the past, in the form of work-based contributions, and to a knowable, predictable future. Social insurance was therefore suited to an age of working-class ascendancy (the commonality of fate) and to a widespread acceptance of the desirability and feasibility of planning (temporal continuity). A naive acceptance of free market globalisation (see Chapter 4) has undermined both of these conditions. Consequently, the income inequalities which the NSD refuses to challenge substantially make the idea of social insurance redundant: the affluent can afford to insure themselves whereas the poor can be helped with targeted forms of assistance. Systems of universal coverage crumble and the lifecycle fragments and splits: in insuring ourselves against risk, it is no longer ' $w e^{\prime}$ who work forward from the determinate past, but ' $\mathrm{I}$ ' who works backwards from an indeterminate future as the solitary entrepreneur of my personal fate (O'Malley, 1992). This is what the 'Americanisation' of social security implies and New Labour has gone even further than its Conservative predecessors in introducing workfare, benefit sanctions, in-work means testing and 'single gateways' which treat all new 
claimants the same, whatever their work record. The affluent are effectively opted out into the private insurance market, especially with regard to pensions and personal security; the poor become subjected to means testing and to forms of control that are benignly authoritarian: the discourse of paternalism becomes indistinguishable from that of control. The movements and schedules of claimants become part of a process of negotiation between themselves and appointed experts; accents, gestures and sartorial appearances (clothing, hairstyles, jewellery, cosmetics) become subject to official scrutiny (Marx, 1995: 228).

Thus the benefit system, never the most benevolent of institutions to begin with, embodies a strategy of 'anticipatory deterrence': whereas it used to be largely re-active, reacting to problems once they had occurred, it is now increasingly pre-active, defining problems in advance and clamping down on any hints of abnormality. The nakedness of this strategy has been most in evidence in the case of asylum seekers and refugees, the internationally homeless, for whom any distinction between social and criminal policy has long become meaningless and when the histories of New Labour are written, their treatment of asylum seekers may well prove to be their greatest shame.

What all of this means is that we do not return to the workhouse of the pre-welfare state, nor do we advance to a post-welfare state of last-resort safety nets; instead, we experience a security state where welfare institutions paternalistically prod and encourage us into deregulated and flexible labour markets (Rose, 1996, 1999). The ethic of state welfare and basic needs is not abandoned; instead, what we need is redefined away from entitlement to material goods towards a duty-led ethic of emotional belonging and social inclusion enforced, where necessary, by the globallyoriented state (Culpitt, 1999; Kemshall, 2002). 'Security' encompasses 'welfare' in order to transcend it. This is the ethics of 'market collectivism' (Fitzpatrick, 1998a). If we do not volunteer to keep ourselves socially and morally fit, ready for the opportunities that the global economy might scatter in our direction, then the state will be on hand to volunteer us instead. The collectivisation of duties occurs because duties are now thought to be orientated to the global; the individualisation of rights occurs because it is assumed that the global cannot accommodate common rights. Citizenship attenuates between two spaces. The social space recoils upon itself despite various compensatory efforts to knit these shrinking spaces into an integrative patchwork, e.g. the European Union; the global space inflates into an immense, vaulting arena, big enough both to amplify the shouts of the angry and drown the cries of the powerless. Being an attenuated citizen now implies localised training for global responsibilities. 
These developments have also been visible within the criminal policies of New Labour's first term and some have argued that by the 2001 general election there was no effective distance between Conservative and New Labour policies on law and order (Downes and Morgan, 2002). Putting to one side forms of electronic surveillance and control (dealt with below), those policies have been characterised by the following four main characteristics.

First, New Labour accepted the 'prison works' philosophy of the Conservatives, the belief that incarceration for individuals is the best way of resolving social problems. The continuities in this respect between Michael Howard and Jack Straw as, respectively, Conservative and Labour Home Secretaries are obvious. By 2002 England and Wales had a higher proportion of its population in jail than China, Saudi Arabia or Turkey, the second highest rate in the EU behind Portugal (Travis, 2002). And although this is still only one-fifth of the rate of incarceration to be found in the USA, it nevertheless represents a similar trend towards a punitive individualism in the context of unjust social inequalities (Christie, 1994; Reiman, 1998).

Second, there has been a preference for targeting repeat offenders and for zero-tolerance campaigns, the 'broken windows' strategy imported from the USA of coming down hard on minor examples of law breaking in the belief that these, if left unattended, will multiply into major incidents through their impact on victims, perpetrators (if left unpunished) and the civic capital of the local community. This zero tolerance has also affected other aspects of civil order with New Labour partly collapsing the distinction between terror and civil disobedience. Again, there is no solid evidence that such strategies work, but they have served the purpose of fuelling tabloid paranoia about the imminent breakdown of society (Garland, 2001).

Third, New Labour has promoted the use of curfews and exclusion orders in order to keep troublemakers either at home at certain times of day or away from certain urban districts altogether. Naming and shaming persistent troublemakers is a means not only of exclusion, but of inclusion: by 'keeping out' we also 'keep in' the law abiding and hard working, so reaffirming norms of civic, communal and familial identification (Braithwaite, 2000). That these powers have been actually deployed much less by local councils and police forces than the government would have liked reflects the belief that pandering to the fear of crime is different to addressing the actuality, not least because perceptions of risk almost always diverge from the reality of risk, with the public consistently overestimating the extent of crime, misidentifying the victims of crime and underestimating rates of incarceration (Pantazis, 2000). 
Fourth, the evidence has struggled with ideology to influence government policy. Civil liberties arguments have been repeatedly denounced as the chatterings of middle-class liberals comfortably separated from the working-class communities where crime palpably affects the quality of life. Therefore, the fear of crime needs addressing, even when those fears are naive or unrealistic (Young, 1999; cf. Taylor, 1999). Targeting 'the criminal' is so important that it can only be infrequently left to juries, 'liberal' judges (hence the need for minimum mandatory sentences) or defence lawyers. But what this populist stance then does is to feed an hysteria that can never be satiated. When paranoia is pandered to rather than challenged, then there is no need for self-limitation, since the politicians and press always say you are right. If asylum seekers are dispersed and given vouchers, then racism is given an official stamp and you can riot; if the courts and prisons are soft then the enemy is always within and you can intimidate a few paedophiles (and settle some old scores along the way); if immigrants are not integrating - otherwise why else would they need language classes? - then there is no need for British identity to change. Ironically then, the separation between civil liberties and social justice not only backfires on New Labour's more liberal tendencies, but leads to a situation where crime seems to be ubiquitous and so quality of life in the very communities New Labour professes to support is always undermined.

This is not to accuse all New Labour's policies of being unremittingly foolish. Just as a preference for targeting has allowed rises in some benefit levels, so the government has been able to sneak in some welcome reforms below the populist radar, e.g. to drug laws and to the police (through the Macpherson Report). It has also resisted the worst excesses of antipaedophile hysteria and the outcry over the Bulger killers' release in 2001. Nevertheless, both social and criminal policies have been willing to reconfigure welfare and need in terms of security and risk, effecting a convergence of conservatism and social democracy around the imperatives of a security state. The distinction between criminal and welfare policies is now less clear than at any time since the nineteenth century.

To summarise, the security state arises as a result of two processes: the conservative assault on the social democratic welfare state, followed by a more limited version of social democracy (the NSD) later accommodating itself to the conservative settlement. The security state is therefore characterised by: (1) large amounts of social inequality, increasingly manifested as spatial polarisation, regulatory instincts, the loss of a commonality of fate and fewer communicative and symbolic interactions between richer and poorer; (2) a pathologisation of social problems where those at the social edges are blamed for their marginalisation, criminalised for being unable or reluctant to become risk takers in the global environment 
that the security state engenders; (3) supply-side reforms where the excluded are to be supervised and remoralised as a condition of their reintegration into the social mainstream, whether through rationalist incentives, normalisation, surveillance or punitiveness. The security state represents not the dismantling of the welfare state, but its incorporation within a punitive ethic of risk and fear. The consolidation and growth of the security state can then be witnessed in the bulk of New Labour's social and criminal policies, and the ways in which those disciplinary boundaries are flimsier than ever. As a last word I suspect that, without a substantial change of direction, New Labour's eventual replacement in power by the Conservatives will produce no greater discontinuities than the replacement of the New Democrats by Bush junior's Republicans in the US.

\section{Information}

We now move on and explore the NSD's relationship to the information society by applying the above lessons. My basic thesis will be that New Labour has conceived of information as being asocial and contextless (reflecting the individualisation of social problems), as commodified (reflecting the hegemony of conservative economics) and as a source of surveillance (reflecting a criminalisation of the supply side). The argument is made through the following four sub-sections. I shall first set out my analytical stance by applying critical theory to information society debates and then review the above characteristics in turn.

\section{Cyber-criticalism}

As perhaps the key contemporary figure in information society debates Castells makes an effective startingpoint. Castells (1996: 470-4) underlines the point that networks are not structureless webs demonstrating no hierarchical features, but grids that flow according to logics of power. Networks may consist of nodes, but some nodes are more powerful than others, exerting a greater gravitational force on the relations that stream around them. He talks of networks being connected by 'switches' that are the privileged instruments of power, i.e. global flows of financial capital, ensuring that the network society is a capitalist society of 'decentralised concentration'.

Having reached this point, however, Castells (1996: 469) then veers towards a postmodernist reading (though he might not accept the description), insisting that ' . . . the power of flows takes precedence over the flows of power.' In short, 
above a diversity of human-flesh capitalists and capitalist groups there is a faceless collective capitalist, made up of financial flows operated by electronic networks.... This network of networks of capital both unifies and commands specific centers of capitalist accumulation, structuring the behaviour of capitalists around their submission to the global network. ... While capitalism still rules, capitalists are randomly incarnated ... (Castells, 1996: 474)

So although capitalism has triumphed, it is potentially vulnerable to changes within the electronically-mediated 'global capital network'. Yet what this does is to remove capitalist agents from capitalism, to treat it as an agentless system where capitalists must submit to their 'random incarnation'. The reason for this move - first recognising power and then emptying it of agency - is because Castells wishes to contrast the 'power of flows' with the 'power of identity', defining the latter as the cultural representations and codes of information around which sociallysignificant mobilisations can form. What Castells (1998: 348) eventually makes clear is his belief that there are no more stable power elites because culture is now the source of power, of capital and therefore of the information age's social hierarchies.

From a critical theoretical perspective, the kernel of truth here masks the fact that when oppositional movements mobilise against global capitalism they do so not only in terms of cultural identities but also in terms of the materiality of the global network that Castells dissolves into informatic signs. Therefore, although he offers hope to oppositional movements, it is the hope of an identity politics divorced from the great economic and ideological struggles of modernity (Castells, 1998: 359). So as well as underestimating the power of capitalist agents, Castells enjoins us to abandon the ideological reference points and strategies that provide such struggles with long-term direction. That most of the social movements he celebrates are perversely unwilling to do so, that ideology may actually motivate micro-political struggles is not something he seems able to accommodate.

One consequence of this is that his observations regarding surveillance practices are too simplistic (Castells, 1997: 299-303). For although he is correct to identify the enhanced surveillance capacity of corporations, Castells seems to believe that this renders forms of centralised surveillance impossible, due to the declining power of the nation-state. But what this analysis does is to neglect the points made above, namely that the security state attempts the reregulation of the micro-social within a global, free market economy. According to this thesis, and as we shall see below, state and corporate forms of surveillance are conjoined in a network where centres and peripheries continually fold into one another.

Cyber-criticalism, then, offers a richer account of surveillance because it does not imagine that the power of flows has overwhelmed flows of 
power. Therefore, the application of critical theory to information society debates requires us to understand how and why traditional hierarchies of power adapt to new technologies, allowing themselves to be reconfigured by them, without being substantially undermined in the process. Cyber-criticalism therefore characterises the work of a number of authors (Sardar and Ravetz, 1996; Perelman, 1998) who identify hierarchical struggles (as always, including class but not limited to it) as a defining feature of 'informatic capitalism'. Let us quickly review two principal contributors.

Herbert Schiller (1981, 1984, 1989, 1996) works with three basic premises. First, informatic capitalism is riven by inequalities between the information rich and poor. This does not mean that the poor are excluded from information per se, merely that ICTs constitute a positional good so that informational inequalities will always be reproduced, even as access to informational networks spreads. Second, that information is subject to market criteria such that the most valuable information is that which can be bought and sold. Increasingly, this implies not information about the goods and signs to be consumed, but information about the audiences who will do the consuming. In short, the marketisation of information engenders the next stage in the capitalist commodification of the self. Third, the advent of informatics strengthens corporate capitalism (van Dijk, 1999). So Schiller lays down the three characteristics of information that I listed earlier: asociality, commodification and surveillance.

Dyer-Witheford (1999) offers a similar but more optimistic reading, relocating cyber-criticalism in an interpretative context that stresses the power of excluded agents to resist and challenge the growing hegemony of informatic capitalism. He cites numerous struggles by class and social movements around the world as evidence that, although the frontiers of information are expanding, the interior spaces of those expanding horizons are vulnerable to opposition and reconfiguration in the direction of radical alternatives.

Therefore, cyber-criticalism agrees with Castells that information networks are significant, but is less ambiguous than Castells appears to be about the political economy of this shift. It treats the information revolution as a revolution within capitalism and not a revolution of capitalism, so that although information flows, it either flows up or down a gradient that, like all stages of capitalism before it, continues to be defined by the state-market nexus (Wyatt et al., 2000; cf. Slevin, 2000: 204-7). Informatic struggles therefore occur between those who use technological systems to assemble peripheries around multiple centres of information flow (call it the Bill Gates approach) and those who exchange and/or disrupt information to resist the state-corporate nexus by peripheralising the centre and breaking it open to the public gaze (Fitzpatrick, 2002c). 
So we can define 'information systems' as the technological infrastructures that form the principal conduits of the informational web, as the flows of power of informatic capitalism, as systems that are also potential sites of both submission/repression and resistance/liberation. I now want to explore those information systems in more detail, relating them to the NSD along the way, in order to explain why the latter offers only a myopic vision of the information society. The next three sections therefore explore the three characteristics already mentioned, focusing more upon examples of submission than resistance.

\section{Asocial information}

Now this is not to claim that New Labour omits any reference to social contexts in its approach to ICTs, as it appears to be fully aware of how social inequalities affect the access to, and use of, information technology. However, having made the link between social inequality and access New Labour has been driven to a series of technological fixes to repair what it sees as the gap between the two (Selwyn, 2002; Hudson, 2003). Its reasoning seems to resemble the following: if we now live in a postindustrial service society and if the job of government is to facilitate social inclusion through the provision of opportunities and assets, then access to ICTs not only requires a technological fix but a fix that is itself a means of addressing social inequalities (Leadbetter, 1999). This reasoning has had several tragicomic results.

For instance, in his 1999 budget Chancellor Gordon Brown set aside $£ 15$ million to provide 100,000 computers under a Computers Within Reach scheme (Humphries, 2002). The scheme's intention was to supply, through the voluntary sector, low-income individuals and families with cheap, secondhand PCs, software and printers. The scheme proved to be fairly disastrous, partly due to poor administration and partly due to recipients lacking the financial resources that would enable them to exercise their intended role as consumers. The scheme was quietly shelved in 2002. Even with the best of intentions, therefore, New Labour missed the point repeatedly made by researchers (e.g. Hellawell, 2001; Nixon and Keeble, 2001) that the digital divide is so embedded in social divides that improving access to technology requires more old-fashioned social policies than the government has been able to contemplate, due to its inability to regard egalitarian redistribution as essential to social justice. This inability has consequently influenced its entire approach.

As articulated by its 1999 White Paper, New Labour has interpreted the ICTs revolution as providing innovation, empowerment, choice, greater convenience and improved opportunities for all. Any problems relate to the difficulties of implementation alone so that 'information exclusion' is 
attributed to a lack of knowledge and skills, with inequalities in socioeconomic resources being pushed into the background; what is largely ignored is the danger of ICTs reinforcing existing power imbalances and injustices. So the White Paper (HMSO, 1999: section 3.19) heralds the arrival of teleclaiming (submitting benefit claims electronically) in terms of an enhancement of efficiency, accuracy and speed in the processing of claims, but ignores, and may implicitly welcome, the possibility of the technology subjecting claimants to bureaucratic harassment, disciplinary sanctions and conditions, and relentless observation of their habits, lifestyles and sexual partnerships. With 'independence' constantly being confused with 'wage earning', the potential disadvantages of integrating administrative systems and databases is wilfully overlooked. In short, what is constantly emphasised in the White Paper is the right of taxpayers to know that their taxes are not being 'wasted' and so, ultimately, it is the taxpayer who is being empowered by ICTs, not the claimant. At one point, the White Paper (HMSO, 1999: section 5.14) does acknowledge the dangers that ICTs can pose through the 'inappropriate transfer of data' and states that government must commit itself to data protection. But who decides what is inappropriate? Is data pertaining to a claimant to be as secure as that pertaining to a non-claimant? The government's obsession with targeting and benefit fraud suggests that it will not. Therefore disasters such as the Computers Within Reach scheme are not accidents, but are rooted in New Labour's hostility to strong equality.

To treat information as asocial, to underestimate the influence of offline upon online environments (Fitzpatrick, 2000), to prioritise national competitiveness and to reach for technological fixes is to reconstruct the citizen as the 'massless citizen'. The 'massless citizen' is the ghostly inhabitant of the information society and the term is meant to conceptualise the fact that with the integration and comparison of computer files, we each have an electronic shadow or doppelganger, a 'data-self' (Lacy, 1996: 162-3; Fisher, 1997: 120). Sometimes this virtual self is nothing more than a cyberreflection of the real person; increasingly though, the flesh and blood person is being treated as an inferior version of their data-shadow, as in the case of a credit check or a CCTV scan. It all depends upon whether we possess our data-selves or are possessed by them. So, somebody does not have to be logged into the Internet to become massless: in a society of information systems, even the most computer-illiterate person is a massless citizen in that they have an online virtuality which is sometimes a simulation of, and sometimes simulates, their offline realities. We are all massless citizens because we are all caught and implicated within the informational webnet of the state-market nexus. So, whereas the term 'digital citizen' focuses simply upon online-offline interactions, 'massless citizen' is meant to encompass both digitality and social hierarchy: the 
'digital hierarchy'. Masslessness implies both virtuality - streams of data that are without mass (photons) - and post-collectivism, i.e. a society where the masses are no longer said to exist; and despite its communitarian discourse, by accepting the post-collectivist settlement of conservatism, it is precisely this shift to an individualist society of social polarities and pathologies that the NSD has perpetuated.

So what New Labour's actual and proposed reforms to social security, health care (Keen et al., 1998) and education add up to is a 'self-service welfare state' where the individual performs many of the functions and roles traditionally performed by administrators (Loader, 1998; Fitzpatrick, 2003a). It also implies a one-stop system where individuals interface with government at a single point as a range of public services become electronically available (Frissen, 1997). Self-service welfare may only enhance a process whereby the state penalises those who demonstrate an inability to look after themselves by enforcing a strong market dependency in a deregulated global economy. In a digital version of the Poor Law, the state may say: here is the information and the technology needed to access it, now solve your own problems, or else!

\section{Information as commodity}

New Labour also has little to say regarding the commodification of information about both employees and consumers (Fitzpatrick, 2002c). With power having shifted towards employers and large corporations, and with New Labour having consolidated that hegemony, employees and consumers are reduced to information bits that are then conceived in terms of profit and loss. The simple, productivist logic of many employers and managers says that since they are paying employees a set rate to perform a job, then they need to know whether they are getting their moneys worth. Unfortunately, workplace surveillance tends to be a oneway system (Sewell, 1996; Marx, 1999; Miller and Weckert, 2000; Moore, 2000). The monitoring of emails and Internet activity is extremely simple, mini surveillance cameras are increasingly prevalent, background checks on employees and job applicants are now easier to run because of datamatching techniques and genetic screening is on the rise, especially in the USA (McCahill and Norris, 1999). Call-centre workers are assessed upon simple, quantified criteria (how long it takes to dispose with each caller), through teleworking it becomes easier to monitor workers at home and dial-in facilities erode the distinction between job and non-job sites. Employees are increasingly judged upon what they may do rather than what they have actually done (Lyon, 2001: 41).

In short, electronically generated information tends to act as information always acts in a market; it is information about the relatively powerless that flows to the relatively powerful. So although there is some 
capacity for good in such surveillance, e.g. to prevent sexual harassment, this is more than outweighed by the dangers of misuse on the part of those who control the systems in question.

Consumption betrays similar preregulatory characteristics (Sklair, 1995) and again New Labour has said little about the inherent dangers here given its reluctance to challenge the conservative agenda substantially. Demand is now increasingly managed through practices that constantly predict future behaviour, based upon past behaviour. As every purchase is logged or every credit card scanned, and as consumers miraculously find their favourite brands on the supermarket shelves in just the right quantities, so the windows of consumption begin to narrow. Demand is matched to supply not only through mass advertising, but because we become our own market researchers. The loyalty or reward card is only the most individualised manifestation of networking technology: the encoding of the purchaser and not just the purchase. ICTs help us to consume more efficiently, but also close off non-consumerist spaces, both because of the allurements of frictionless consumption and because those same databases easily become means of surveying those who will not or cannot browse the shelves.

Furthermore, the body is no longer a simple appendage to the machine, but what some like to call a terminal plugged into the informatic circuitry. The cyborg is neither just a metaphor (Haraway, 1991) nor a physical assemblage of machine and organism, but a risk processor that increasingly simulates an informational system by relating to its environment as a series of dichotomous zeroes and ones: threatening/non-threatening, insider/outsider, same/other (Fitzpatrick, 1999b).

Nor does net surfing allow us to erase the traces that we leave behind us. Our own computers store data about us through 'cookies' that can be accessed by commercial interests (Lyon, 2001). Though apparently conducted in secret, journeys in cyberspace emit visible electronic trails that can be accessed by those with the means and the software to do so. Such electronic information is generated for the ultimate benefit of capital accumulation and permits the ideology of exchange value to invade personal areas of life, e.g. leisure time, with greater ease than ever before. And because the information available to consumers remains limited (not revealing, for instance, the impact that the production of goods may have had upon the environment or upon the lives of workers in the developing world), then it acts as something of a barrier to anticonsumerist forms of social interaction and political mobilisation.

\section{Information as surveillance}

But if surveillance is generated by a logic that fetishises market commodities, it is also driven by the security state itself (Fitzpatrick, 2002c). 
As information systems make it theoretically easier for people to gather information upon those who rule them, both commercially and politically, so it becomes easier for the latter to justify the gathering of information on the former (William and Webster, 1999: 129). Convenience and accessibility become the watchwords of both the commercial and political worlds: the frictionless flow and instantaneous exchange of information. Of course, possession of information about the governed is an inherent feature of governance and over the last century, the welfare state was instrumental in accelerating the gathering of information. Cradle-to-grave provision requires the tagging and monitoring of the employment, contributory, educational, marital and medical histories of its citizens, a bureaucratic and administrative machine that files, catalogues, indexes and processes you in hundreds of ways (Lyon, 1994: 94-6). But as the welfare state mutates into the security state, as needs are reconfigured as risks and fears, so policy-makers propel surveillance into new realms.

The most obvious example of covert surveillance is the spread of CCTVs. 'Covert' not in their visibility (which is deliberately prominent, though people still underestimate their prevalence), but in their insidious effects upon the public sphere: the will to govern strengthens as the macro-state shrivels (Smith, 2000). Those effects are being chartered by an increasing amount of research and scholarship (Coleman and Sim, 2000; Williams and Johnstone, 2000) and so Norris and Armstrong (1999) are not alone in concluding that CCTVs are used in accordance with the existing structures of social power: by and large, the cameras are there to defend commercial and affluent areas and camera operators survey those they perceive as being socially excluded according to popular prejudice. CCTVs may be popular with local politicians and administrators, due to the need for cities to maintain social order, so that they may advertise themselves as desirable objects of global investment (Sassen, 1991) within the security state. With such attitudes in place the way is clear for surveillance cameras to be increasingly computerised so that images (faces, behaviour, licence plates) can be scanned, digitised and compared to various databases. This has already led to the blanket scanning of public areas and the technological presumption of guilt in crowds of postanonymity. CCTVs enable databases to grow which, in turn, justify the use of CCTVs, and so on. Cameras do not see people, they see classifications into which digital images may or may not fit and some allege that ever more sophisticated, algorithmic forms of surveillance are imminent in order that those categories can be multiplied and applied indefinitely (Graham and Wood, 2003).

But as well as facilitating covert surveillance, New Labour also operates more overt forms. Let us take two recent controversies. The Regula- 
tion of Investigatory Powers Act (RIPA) came into force in the UK in October 2000 (Calleja, 2000). The Act sets out the procedures by which the security services and the police can monitor and access electronicallymediated communications. For instance, they are now able to track communications data - the websites and newsgroups individuals visit and the addresses of their email correspondents - through the use of 'black box' technology, effectively transforming service providers into wiretappers for the state. If criminal activity is suspected, then the security services can apply for a warrant to intercept and decode the actual content of such Internet traffic. The original bill was particularly draconian and came under sustained attack. Critics were able to argue that New Labour was allowing its authoritarian instincts to dominate and allowing 'gee whiz' technological determinism to shape the agenda. This opposition was successful, but only partially so.

So even though the RIPA is preferable to the preceding bill, its powers invade privacy to a far greater extent than previous interception procedures and the criteria for the release of warrants is not as stringent as it should be. Additionally, if that content is encrypted then the individual in question is required to surrender the encryption keys or face a jail sentence of up to two years - or even five years if they reveal to a third party that the surveillance warrant exists. Initially, the burden of proof was entirely on individuals to establish that they had lost or forgotten their keys, i.e. that they were guilty until they could prove themselves innocent. The government backtracked and the Act requires the prosecution to prove that individuals have not done all they can to recover a key. However, critics like Liberty and Stand allege that the burden of proof in UK law has been undermined and that, bizarrely, those whose criminal activities would otherwise attract longer jail sentences can now opt for a shorter sentence by refusing to surrender their keys.

The second controversy concerns New Labour's foray into biometrics. Biometric technologies are those that employ the body as a site of identification and surveillance (Nelkin and Andrews, 1999; Andrews and Nelkin, 2001) where we are identifiable through our physical characteristics: voice, face, eyes, fingerprints, palmprints and DNA. Increasingly, then, existing forms of identification are likely to merge with biometric technology, with the latter protecting the information contained on smart cards and credit cards and such cards being used to store biometric data. So biometrics has a wide range of applications, from welfare institutions such as the benefits and health-care systems through to the criminal justice system. DNA fingerprinting is an obvious form of biometrics that is now a commonplace procedure (Krawczak and Schmidtke, 1998) and many are now calling for the expansion of DNA registers and databases (Blume, 2000). 
Those who worry that biometric technology may encourage an increase in institutional coercion, error and alienation (Lyon, 2001) were not reassured by New Labour's expansion of biometric surveillance. In January 2001 New Labour presented to Parliament the Criminal Justice and Police Bill. Receiving the Royal Assent in May 2001, this was to allow the police to retain fingerprints and DNA profiles from individuals suspected of a crime, even when they are not subsequently prosecuted or when they are acquitted of a crime. DNA samples will also be retained when they have been volunteered during a mass screening programme by the police. Written consent from the donor must be obtained but, once given, that consent can never be revoked.

New Labour offered five main justifications for this extension of police powers. First, that it will help to fight crime, especially crimes perpetrated by habitual criminals, because the DNA of those individuals will already be on record. Second, it will help to eliminate innocent people from suspicion and law-abiding people in general have nothing to fear from extensive DNA databanks. Third, safeguards to prevent abuse will be ensured. Fourth, a DNA profile is an 'objective form of evidence' which should no more be thrown away than other pieces of evidence, e.g. interview notes - the quote comes from Home Secretary Jack Straw in the Commons on 29 January 2001. Finally, too much time and expense is wasted in reprofiling those who have already been profiled in a mass screening programme. Do these reasons bear scrutiny?

If fighting crime is such an overwhelming priority, then why not require everyone in the country to provide a DNA sample (including newborn babies)? Politicians who claim that large DNA databanks are popular know that they are not this popular. Yet even if they were there can be no mandate for the abandonment of basic civil liberties and even those politicians who disagree might hesitate to compel millions of noncompliers to surrender DNA samples. Much easier then to allow the databanks to be built up from those who come within the purview of the police since, as is well known, it is individuals who commit crimes and not social conditions! This is a pathological argument which overlooks the extent to which crime is socially and discursively constructed. Almost inevitably, such databanks will contain a disproportionate amount of DNA samples from the poorest and most vulnerable.

The endless refrain that the innocent have nothing to fear is the usual Orwellian means of neutering the civil liberties argument that the proper distinction is not between the innocent and the guilty, but between the relatively powerless and the relatively powerful. In fact, the relatively powerless do have something to fear whenever the presumption of innocence shifts towards a presumption of guilt. Yet in denying this what the Orwellian refrain does is to employ an actuarial logic where individuals 
are required to obey the norms that define them as moral/insiders rather than immoral/outsiders. Yet since there is no system that is immune to abuse and errors 'the innocent' do have something to fear and only a naive technological determinism can pretend otherwise.

The claim that a DNA profile is an objective piece of evidence is even more disturbing. Not just because a piece of evidence is objective only in conjunction with other pieces of evidence (a DNA-yielding hair found at a crime scene may have been planted), but because Straw's claim reduces DNA to the status of an interview note rather than as something that yields vital personal information about us. The commodification of society that Schiller warns against has engendered the criminalisation of society for, as Bauman (1998a) notes, those who cannot or will not be seduced by the commodity form are immediately suspected as being threats to it. Therefore the commodification of the body also engenders the criminalisation of the body as its logical extension: what I earlier referred to as the security state's criminalisation of the supply side. After all, why not treat genetic tissue and body parts as just another processable piece of matter if crime is of such overwhelming concern?

Finally, what of the idea that, once given, written consent for the retention of DNA samples taken during mass screening programmes cannot be revoked? As the then Home Office minister Charles Clarke pointed out, if consent can be revoked at a later time, then we have barely changed the current situation where samples are automatically destroyed. Clarke was actually being quite honest: a managerialist logic that values centralisation, efficiency and cost effectiveness above liberty and autonomy is one that demands the non-revocation of consent.

\section{Conclusion}

I warned you earlier that we would be examining the repressive rather than the liberatory aspects of information systems and it is worth repeating now that the worrying trends identified above do not mean that we are sinking inevitably into a one-dimensional society of surveillance. Surveillance, even in some of its less appealing roles, can have socially beneficial effects if, say, it helps to reduce traffic congestion or protects children from abuse - mobile-phone robberies notwithstanding! Further, ICTs also permit forms of counter-surveillance and counter-hegemonic activity through which the gaze of employers, corporations and the security state is redirected (Fitzpatrick, 2002c). Yet these qualifications aside, I have wanted to stress New Labour's role in promoting an information society that is drifting towards some disturbing ends. Sometimes covertly and sometimes overtly, sometimes consciously and sometimes not, New 
Labour is ushering us towards a society where civil liberties, like social justice, are constantly on the defensive.

In the previous chapter I outlined New Labour's preference for weak equality and strong reciprocity and in this chapter I have wanted to suggest that, by tipping the balance away from redistributive rights and towards duty-led inclusivity, this preference both derives from and further engenders a security state. As an amalgamation of conservatism and social democracy, the security state has not replaced the welfare state, but subsumed it within a society (1) of social and spatial polarities; (2) where social problems are pathologised; and (3) of punitive supply-side reforms. These dimensions are then visible with New Labour's approach towards ICTs, where information is conceived as asocial, as commodified and primarily as a source of surveillance. Along the way, I have hinted at an alternative approach, one that I termed 'cyber-criticalism'. Like the theory of distributive justice offered in the last chapter, we will now put this to one side until Part II.

So we are almost ready to proceed to Part II and to the outline of ecowelfare contained there. However, before we can do so there is one highly important and influential defence of the NSD that we have not yet considered at any length.

\section{Note}

1 Although I am focusing upon global developments throughout the 1990s, I believe that developments since 11 September 2001 help to confirm my hypothesis, since the most extreme and hysterical reactions to the attack in the West have occurred in the paradigm examples of the security state, i.e. it is in the USA and UK that civil liberties have been subjected to the greatest threat. People (if governments and newspapers are to be believed) appear more willing than ever to sacrifice freedom (their own and that of others) in exchange for security. And this security often takes the form of pre-emptive intervention against the Other, no matter how remote or improbable the imagined threat. 